\title{
Samvinna framhaldsskólanemenda: Liður í lærdómi til lýðræðis
}

\author{
Gerður G. Óskarsdóttir
}

$\checkmark$ Abstract Um höfundinn $>$ About the author Heimildir

Lýðræði í skólastarfi hefur borið hátt í alpjóðlegri umræðu um og eftir síðustu aldamót í kjölfar verkefna Evrópuráðsins og Evrópusambandsins um lýðræði í menntun og borgaravitund. Áhrifa peirra gætir í íslenskum aðalnámskrám frá 2011. Í aðalnámskrá framhaldsskóla frá 2011 segir meðal annars að starfshættir skólanna skuli mótast af lýðræðislegu samstarfi. Samvinna nemenda um lausn viðfangsefna námsins er einn af lykilpáttum lýðræðislegra náms- og kennsluhátta. Markmið greinarinnar er að varpa ljósi á tíðni, umfang og skipulag samvinnu framhaldsskólanemenda í kennslustundum og viðhorf nemenda til hennar. Byggt er á vettvangslýsingum á 130 kennslustundum (167 klukkustundum) í níu framhaldsskólum og viðtölum við 17 nemeßndahópa úr rannsókninni Starfshættir í framhaldsskólum. Gögn voru greind í ljósi fjölpjóðlegrar stefnumörkunar og námskrár par sem lögð er áhersla á lýðræðislegt samstarf. Niðurstöður um tíðni leiddu í ljós að einhvers konar samvinna fór fram í 47 kennslustundum (af 130 stundum) eða 36\% heildarstundanna. Við athugun á umfangi kom fram að samvinna átti sér stað í 17\% heildarkennslutímans (fjöldi mínútna talinn). Allnokkur munur kom fram milli skóla og námsgreina. Í einum skólanna var um 34\% heildartímans varið í samvinnu en aðeins um 3\% tímans í öðrum. Meiri tíma var varið í samvinnu í íslensku og erlendum tungumálum en í öðrum námsgreinaflokkum. Ekki kom fram munur á umfangi samvinnu milli byrjendaáfanga og framhaldsáfanga. Nemendafjöldi í námshópi eða uppröðun húsgagna virtist ekki skipta meginmáli í pessum efnum. Við greiningu á skipulagi voru skilgreindir prír flokkar samstarfs: a) Hópvinna eða samvinnunám skipulagt af kennara og nemendur unnu síðan að lausn viðfangsefnis sameiginlega í einstökum hópum (59\% heildartímans sem fór í samvinnu); b) Hópvinna sem kennari sagði fyrir um, en nemendur í einstökum hópum skiptu með sér verkum og unnu síðan að mestu einslega (25\%); c) Valfrjáls hópvinna par sem kennari sagði að nemendur mættu vinna saman í hópum og meirihluti nemenda kaus að gera pað (16\%). Jafnframt var sjónum beint að hópskipan, hlutverki í hópi, hópstærð og markmiðssetningu. Viðhorfum nemenda til samvinnu er fléttað inn í umfjöllunina.

Efnisorð: samvinna/samstarf, lýðræðislegir starfshættir, hópvinna, samvinnunám, framhaldsskóli

\section{Inngangur}

Lýðræði í skólastarfi og menntun til lýðræðislegrar borgaravitundar hefur verið í brennidepli alpjóðlegrar umræðu um skólastarf frá pví á árunum um og eftir síðustu aldamót. Hún hefur meðal annars mótast af átaki Evrópuráđsins sem beinist að námi um lýðræði, í lýðræði og til lýðræðis (Evrópuráđið, 2010) og stefnumörkun Evrópusambandsins um menntun til borgaravitundar (European Commission/EACEA/Eurydice, 2017). Sama anda má greina í Barnasáttmála 
Sameinuðu pjóðanna (1989) og hugmyndum um réttindaskóla UNICEF (UNICEF á Íslandi, 2015). Íslenskar aðalnámskrár frá 2011 taka mið af fyrrnefndum áherslum, en lýðræði og mannréttindi er einn af sex grunnpáttum menntunar á leik-, grunn- og framhaldsskólastigi (Mennta- og menningarmálaráđuneyti, 2011a, b, c). Í almennum hluta aðalnámskrár framhaldsskóla (Menntaog menningarmálaráðuneyti, 2011c) segir meðal annars að starfshættir skólanna skuli mótast af lýðræðislegu samstarfi. Menntastofnunum er pannig ætlað mikilvægt hlutverk í próun lýðræðisins.

Ekki liggur reyndar ljóst fyrir hvað felst í námi til lýðræðis. Engu að síður má fullyrða að samvinna af margvíslegu tagi innan og utan skólans sé meðal lykilpátta lýðræðislegra starfshátta skóla, frjó leið til pess að læra í og til lýðræðis (Gollob, Huddleston, Krapf, Rowe og Taelman, 2008). Í daglegu starfi í skólastofunni má líta á samvinnu nemenda við lausn viðfangsefna sem einn grundvallarpátt náms í lýðræði - sem er mikilvægur liður í uppeldi til lýðræðislegrar pátttöku. Pegar vel tekst til kallar hún á að samstarfsfólk í hópi setji sér starfsreglur, semji um verkaskiptingu, taki tillit til sjónarmiða annarra, leysi ágreiningsmál og skynji kröfu um að leggja sitt af mörkum. Hópfélagar átti sig jafnframt á annmörkum og vandamálum sem upp koma pegar ólíkar áherslur og sjónarmið koma fram eða ójafnvægi er í virkni. Pótt starf í hópi purfi ekki alltaf að vera lýðræðislegt, pá ætti hópstarfí námi ætíð að sverja sig í ætt við lýðræði.

Umræðan um mikilvægi samstarfs nemenda í náminu er ekki ný af nálinni. Hún á sér langa sögu 1 fræðilegri umfjöllun um kennsluhætti sem eru hluti af heildarstarfsháttum skóla. Frá Dewey (1916/1966) til vorra daga hefur sérstaklega verið dregið fram mikilvægi og ávinningur samvinnu (Laal og Laal, 2012; Slavin, Hurley og Chamberlain, 2003). Skipulag samvinnu getur verið af ýmsum toga. Gerður hefur verið greinarmunur á svonefndu samvinnunámi, gjarnan undir stjórn kennara, og hópvinnu nemenda sem oftar en ekki er nemendastýrð (Panitz, 1999; Slavin, 2014).

Á pessum grunni er áhugavert að beina sjónum að peim pætti lýðræðislegra vinnubragða sem felst 1 samvinnu nemenda um lausn viðfangsefna námsins. Markmið greinarinnar er að varpa ljósi á tíðni, umfang og skipulag samvinnu framhaldsskólanemenda í kennslustundum og viðhorf nemenda til hennar. Niðurstöður eru greindar í ljósi stefnumörkunar um lýðræðislegt samstarf í fjölpjóðlegu samhengi sem námskráin fellur undir.

Í brennidepli er hvers kyns samstarf tveggja eða fleiri nemenda að tilhlutan kennara. Hugtökin samvinna og samstarf eru notuð jöfnum höndum yfir sama fyrirbærið, pað að vinna saman að viðfangsefni. (Dessi hugtök eru einnig notuð á víxl í íslensku aðalnámskránum og fylgiriti peirra um lýðræði og mannréttindi). Greinarmunur er gerður á formlegu samvinnunámi og frekar óformlegri hópvinnu nemenda.

\section{Stefnumörkun, kenningar og rannsóknir á samvinnu}

Hér er fyrst fjallað um samvinnu sem lið í lýðræðislegum náms- og kennsluháttum með vísan í fjölpjóðlega jafnt sem innlenda stefnumörkun og fræðin að baki. Pá er ræett um gildi samvinnu og kenningar um mismunandi skipulag hennar, annars vegar í samvinnunámi og hins vegar í hópvinnu. Loks er sagt frá niðurstöđum rannsókna á samvinnu nemenda.

\section{Samvinna í lýðræði - stefnumörkun}

Átak Evrópuráðsins um lýðræðismenntun um og eftir síðustu aldamót hleypti krafti í umræðu um lýðræði í skólastarfi. Par var áherslan á að læra um lýðræði, í lýðræði og til lýðræðis (Evrópuráđið, 2010; Wolfgang Edelstein, 2008, 2010). Sáttmáli ráđsins um lýðræðis- og mannréttindamenntun var sampykktur árið 2010, en á vegum pess er litið á lýðræðismenntun og mannréttindamenntun sem samofin fyrirbæri (Evrópuráðið, 2010). Dar er meðal annars fjallað um pjálfun kennara í viðeigandi kennsluaðferðum í lýðræðismenntun. Ýmiss konar aðgerðir, útgáfur og leiðbeiningar um lýðræðislega kennsluhætti fylgdu í kjölfarið (Keating, 2009; Gollob o.fl., 2008). Verkefni framkvæmdastjórnar Evrópusambandsins um menntun til lýðræðislegrar borgaravitundar fylgir 
sama præði, en par er einn af fjórum skilgreindum lykilpáttum að styðja nemendur í að próa með sér uppbyggilega samskipta- og samstarfshæfni (European Commission o.fl., 2017).

Í Barnasáttmála Sameinuðu pjóðanna (1989), sem lögð voru drög að á níunda áratug síðustu aldar, má pegar sjá sömu lýðræðishugsun. Par segir að menntun barns skuli beinast að hæfni til að „lifa ábyrgu lífi í frjálsu pjóðfélagi, í anda skilnings, friðar, umburðarlyndis, jafnréttis karla og kvenna og vináttu milli allra pjóða, pjóðhátta-, pjóðernis- og trúarhópa“ (29. gr.). Sá lýðræðisandi sem parna svífur yfir vötnunum hlýtur að gera sterka kröfu um pjálfun í lýðræðislegum starfsháttum. Nýlega urðu nokkrir skólar hér á landi svokallaðir réttindaskólar UNICEF. Í peim er ætlunin að byggja upp lýðræðislegt námsumhverfi á grundvelli Barnasáttmálans og annarrar stefnumörkunar um mannréttindi og lýðræði. Markmiðið er að æfa börn og unglinga í lýðræðislegum vinnubrögðum (UNICEF á Íslandi, 2015).

Sá lýðræðispráđur sem ofinn var í gildandi aðalnámskrár hér á landi er spunninn undir áhrifum fyrrgreindrar alpjóðlegrar umræðu, meðal annars fyrir tilstilli Evrópuráđsins og Evrópusambandsins, eins og á við um námskrár í fjölmörgum öðrum Evrópulöndum (European Commission o.fl., 2017). En lýðræði og mannréttindi eru einn af sex grunnpáttum aðalnámskrár framhaldsskóla frá 2011 (Mennta- og menningarmálaráđuneyti, 2011c). Gert er rád fyrir að börn og ungmenni læri til lýðræðis með pví að læra annars vegar um lýðræði til undirbúnings fyrir pátttöku í lýðræðissamfélagi (inntak) og hins vegar í lýðræði, pað er í daglegum lýðræðislegum starfsháttum (framkvæmd). Rík áhersla er bví á hæfni nemenda í samvinnu, eins og fram kemur í almenna hluta námskrárinnar: „Starfshættir skólanna skulu mótast af ... lýðræðislegu samstarfi““ (bls. 11). Í lýsingu á fyrsta hæfniprepi af fjórum segir jafnframt: Nemandi ,getur átt jákvæ[tt] og uppbyggileg[t] ... samstarf við annað fólk “ (bls. 43). Lýðræðisáherslan í námskrá framhaldsskóla á sér stoð í 2. grein framhaldsskólalaga frá 2008 par sem segir að hlutverk framhaldsskóla sé meðal annars , að stuðla að ... virkri pátttöku [nemenda] í lýðræðispjóðfélagi með pví að bjóða hverjum nemanda nám við hæfi,“ án pess pó að pað sé skýrt nánar (Lög um framhaldsskóla nr. 92/2008). Pannig er skólum greinilega ætlað að gegna stóru hlutverki í peirri viðleitni að ala æskufólk upp til pátttöku í lýðræðissamfélagi og samvinna peirra í náminu er hluti par af. Í sérstöku pemahefti um lýðræði og mannréttindi sem fylgir námskránum frá 2011 segir til áréttingar að lýðræði snúist ekki um ,að sigra heldur um að taka pátt, pað snýst ekki um samkeppni heldur um samvinnu“ (Ólafur Páll Jónsson og Póra Björg Sigurðardóttir, 2012). Hér endurspeglast fyrrnefnd sýn á að grundvallarpættir lýðræðis verði ekki lærðir nema með samskiptum og samstarfi við aðra (Slavin o.fl., 2003; Wolfgang Edelstein, 2010).

Í upphafi síðustu aldar fjallaði Dewey (1916/1966) um lýðræði og menntun og beindi sjónum meðal annars að samstarfi nemenda um lausn viðfangsefna. Hann hélt pví fram að hlutverk kennara væri að skapa skilyrði sem stuðluðu að samstarfi og paulhugsa pyrfti skipulagninguna fyrir fram, en taumhaldið lægi í vinnunni sem allir tækju pátt í. Hann sá framtíðarskólann fyrir sér sem lifandi samfélag par sem nemandinn væri virkur pátttakandi og samvinna nemenda undir handleiðslu og stjórn kennara væri í brennidepli, með öðrum orðum einkenndist af lýðræðislegum vinnubrögðum. En vart væri unnt að tala um lýðræðislegt samfélag ef pegnarnir hefðu ekki tamið sér lýðræðisleg viðhorf og framgangsmáta í samskiptum og samvinnu (Dewey, 1916/1966, 1934/2010, 1938/2000; Ólafur Páll Jónsson, 2010). Í sama anda rökstyður Wolfgang Edelstein (2010) аð pað purfi að læra til lýðræðis í lýðræði, ef við kjósum að lifa við lýðræðisleg lífsform. Færni í lýðræðislegu samstarfi krefjist æfingar, lýðræði verði að læra og verkefni skólans sé að veita pá reynslu. Út frá sömu sýn er lögð áhersla á að ræktun borgaravitundar nemenda fari fram í gegnum lýðræðisleg vinnubrögð í náminu (Maitles og Gilchrist, 2005; Sigrún Aðalbjarnardóttir, 2015).

Nú á tímum er áhersla á menntun til lýðræðis ekki síst mikilvæg í ljósi merkja um hnignun lýðræðis í heiminum og dvínandi bjartsýni á lýðræðið, sem sjá má af próun stjórnmála, vaxandi völdum alpjóðlegra auðhringa yfir pjóðríkjum og ekki síst hernaðar- og hryðjuverkaógninni (Humes, 2017; Tam, 2018). Við pessar aðstæður á vel við að sækja í brunn Deweys og minna á pau orð hans að lýðræðið purfi í raun að endurfæðast með hverri kynslóð (Hewitt, 2006). 


\section{Gildi samvinnu og skipulag - samvinnunám og hópvinna}

Í pessari grein er byggt á peim grunni að samvinna nemenda í margvíslegum samstarfsverkefnum sé mikilvægur liður í uppeldi til lýðræðislegrar pátttöku. Samvinna nemenda við lausn viðfangsefna í kennslustofunni er hluti par af. Dví er vert að varpa ljósi á fræðilega umræðu um gildi samvinnunnar og mismunandi skipulag hennar.

Fræðimenn sem fjalla um gildi samvinnu nemenda byggja gjarnan á peim rökum að hún bæti námsárangur, efli skuldbindingu, styrki sjálfsmynd og stuðli að auknum félagslegum proska og jöfnuði. Deir hvetja pví til slíkra kennsluhátta, pótt nálgun peirra á viðfangsefnið sé ólík (Farmer, 2017; Johnson og Johnson, 1991, 1999; Slavin, 2014; Slavin o.fl., 2003). Deir sem aðhyllast kenningar um áhugahvöt og félagslega samheldni benda á að samskipti nemenda um viðfangsefni í náminu stuðli í sjálfu sér að betri árangri. Nemendur læri hvert af öđru pví í samvinnu peirra komi upp ágreiningur og flett sé ofan af ófullnægjandi rökum. Dar með öðlist pátttakendur dýpri skilning en ella á viðfangsefninu og hljóti pjálfun í félagslegum samskiptum. Deir sem aftur á móti byggja á kenningu um vitsmunalegan skilning draga fram gildi pess að hópfélagar hlusti hvert á annað og skiptist á að rifja upp eða útskýra efnið. En viðurkennt er að par með sé ekki tryggt að allir skilji inntakið, taki pátt eða geti leyst viðfangsefnið (Slavin o.fl., 2003). Bæta má við peim rökum að með samvinnu í hópi skapist aukið rými til sköpunar og frumkvæðis pegar allir hópfélagarnir leggja fram hugmyndir sínar og mismunandi lausnir. Í nýlegri rannsókn kom fram að samvinnuverkefni veittu nemendum mun frekar tækifæri til frumkvæðis og sköpunar en einstaklingsverkefni (Gerður G. Óskarsdóttir, 2018).

Greinarmunur hefur verið gerður á svonefndu samvinnunámi og ýmiss konar hópvinnu sem náms- og kennsluaðferðum (Davidson og Major, 2014). Samvinnunám (samheiti: samvirkt nám) (e. cooperative learning) sem kennsluaðferð er skipulagt af kennara sem leggur ákveðið viðfangsefni fyrir hóp tveggja eða fleiri nemenda með skýru markmiði. Deim er síðan ætlað að skila ákveðinni lokaafurð eða ná markmiðinu sameiginlega. Kennarinn skipuleggur oftar en ekki niðurröðun í hópa og hlutverk hvers og eins. Kveðið er skýrt á um að framlag hvers einstaklings 1 hópnum skipti höfuðmáli svo markmiði verði náð. Lausn viðfangsefnis felst í að hugleiða pað í sameiningu, leita aðstoðar hvert hjá öðru, deila pekkingu, skilningi og viðhorfum og setja sig hvert í annars spor. Námið er pá hugsað sem félagslegt lærdómsferli par sem allir leggja sitt af mörkum og próa par með pekkingu sína og skilning sameiginlega (Arató, 2015; Davidson og Major, 2014; Ingvar Sigurgeirsson, 2013; Johnson og Johnson, 1999; Joyce, Weil og Calhoun, 2015; Kagan og Kagan, 2009; Laal og Laal, 2012; Panitz, 1999; Slavin, 2008; Slavin o.fl., 2003). Johnson og Johnson (1999) lögðu áherslu á að megineinkenni samvinnunáms væri í stuttu máli að nemendur ynnu saman að bví að ná sameiginlegu námsmarkmiði.

Margir fræðimenn tala aftur á móti frekar um margvíslega hópvinnu í námi og pá í sumum tilfellum sem regnhlífarhugtak sem getur nád yfir hvers kyns formlega eða óformlega samvinnu tveggja eða fleiri nemenda fyrir tilmæli kennara eða að peirra vali (hér er notað orðið hópvinna par um; e. collaborative learning, group work). Tilgangurinn er að nemendur læri hvert af öðru eða styðjist með einhverjum hætti hvert við annað og hjálpist að við námið (Davidson og Major, 2014; Laal og Laal, 2012; Panitz, 1999). Samstarfið felst 1 à tala sig niður á lausn sem getur verið pekkt eða nemendur fá tækifæri til að skapa nýja. Reyndar er viðurkennt að sumir nemendur geta orðið utanveltu í sjálfvöldum og sjálfstýrðum hópum, og pá einkum nemendur sem ekki er vænst að leggi mikið af mörkum til vinnunnar (Panitz, 1999; Slavin o.fl., 2003).

Samkvæmt fyrrnefndum skilgreiningum getur munurinn á samvinnunámi og hópvinnu af margvíslegu tagi meðal annars falist í pví að samvinnunám er skipulagt fyrir fram af kennara, stundum í samvinnu við nemendur, og pví er að einhverju leyti stýrt af kennara. Aftur á móti er framkvæmd hópvinnu frekar nemendastýrð, pó svo að kennari hafi mælt fyrir um hana. Dá eru nemendur með stjórnina í sínum höndum, skipa sér oft og tíðum sjálf í hópa og takast á við viðfangefnið eftir eigin skipulagi. Sumir líta á samvinnunám sem fyrra stig í ferli par sem yngri nemendur eru pjálfaðir með markvissum hætti í að vinna saman, en pegar fram líði stundir fari 
eldri nemendur að stýra hópvinnunni meira sjálf eftir að hafa lært til verka, pó í samvinnu við kennarann (Bruffee, 1995; Davidson og Major, 2014; Panitz, 1999).

Rannsóknir benda til pess að samvinna nemenda, í hvaða formi sem er, hafi jákvæð áhrifá árangur, félagslega hæfni, áhugahvöt og sjálfsmynd í flestum námsgreinum og á öllum námsstigum, eins og fyrr kom fram. Fræðimenn virðast aftur á móti ósammála um pað hvaða aðstæður geri samstarf áhrifaríkt og ekki liggur fyrir nein ein skýring á árangri samvinnunnar. Pví hefur athyglin beinst аð peim kringumstæðum sem gera hvers kyns samvinnu árangursríka (Slavin, 2008; Slavin o.fl., 2003). Tvennt parf til, að mati Slavin (2008), til að samvinnuverkefni skili peirri útkomu sem til er ætlast. Hópurinn parf annars vegar af hafa skýrt hópmarkmið sem útheimtir að allir vinni saman svo pví verði náð (e. group goals), og hins vegar parf að vera ljóst hvert er hlutverk og ábyrgð hvers og eins í hópnum (e. individual accountability) - hvort tveggja einkenni samvinnunáms samkvæmt fyrrgreindum skilgreiningum. Verkefni hópsins er pví ekki metið eða umbun veitt eingöngu eftir útkomunni, heldur einnig eftir framlagi og framförum hvers og eins. Pað hvetji til pess að allir séu með á nótunum og komi pannig í veg fyrir „laumufarbega“ (e. free riding, social loafing) eða áhangendur (e. freeloaders). Rannsóknir benda til pess að endurgjöf til hópsins í heild eða allra í hópnum stuðli að góðum árangri og geti fyrirbyggt að sumir verði settir hjá (Slavin o.fl., 2003).

Mjög misjafnt er raunar hvernig hugtökin sem hér eru til umræðu, pað er samvinnunám (eða samvirkt nám) og hópvinna, eru skilgreind og greinilega ekki samstaða par um. Bent hefur verið á að í samstarfi nemenda af hvaða tagi sem er megi yfirleitt finna blöndu af pessu tvennu og jafnvel fleiri aðferðum og pví skipti ekki meginmáli hvaða heiti pessum kennsluaðferðum eru gefin (Davidson og Major, 2014). Sjá í pessu sambandi umfjöllun í inngangi greinarinnar um samvinnu sem einn grundvallarpátt náms í lýðræði og hvað mætti einkenna hana.

Ljóst er að skilningur á mikilvægi hvers konar samstarfs í skólum, á vinnustöðum og í lífinu yfirleitt er mjög almennur nú á tímum og að áherslan hefur færst frá viðleitni einstaklingsins yfir í margvíslega hópvinnu og samábyrgð (Laal og Laal, 2012). Í pessari grein er horft mjög vítt á allar birtingarmyndir samvinnu nemenda í náminu.

\section{Rannsóknir á samvinnu nemenda í námi}

Samvinna nemenda í námi virðist ekki vera viðamikil í raun prátt fyrir fyrrnefndar áherslur í fjölpjóðlegri stefnumörkun og námskrám (Slavin o.fl., 2003), en rannsóknir á tíðni eða umfangi samvinnu eru reyndar ekki auðfundnar. Í samantekt á rannsóknum frá Noregi og Svíbjóð kom í ljós að ýmiss konar hópvinna tók um 12-18\% kennslutímans (Carlgren, Klette, Mýrdal, Schnack og Simola, 2006). Í bandarískri rannsókn í framhaldsskólum var petta hlutfall innan við 10\%. Dar var bent á að ekki var alltaf unnið saman að viðkomandi viðfangsefni pótt setið væri í hópum, heldur unnu nemendur hver fyrir sig (Goodlad, 2004). Einnig hefur komi fram að samvinna nemenda fái lítið rými í kennslustundum í íslenskum framhaldsskólum (Hafdís Ingvarsdóttir, 2004). Önnur nálgun í kennslu hefur greinilega forgang, en langflestar kennsluaðferðir féllu í flokk útlistunarkennslu annars vegar og pjálfunaræfinga og skriflegra verkefna á einstaklingsgrundvelli hins vegar í rannsókn á tíðni kennsluaðferða í íslenskum framhaldsskólum (Ingvar Sigurgeirsson, Elsa Eiríksdóttir og Ingólfur Ásgeir Jóhannesson, 2018). Hópvinna fór fram í um 10\% heildarkennslutímans í rannsókn á fyrstu önn í reykvískum framhaldsskólum (Gerður G. Óskarsdóttir, 2012) og sama hlutfall kom fram í rannsókn á íslenskukennslu á framhaldsskólastigi (Svanhildur Kr. Sverrisdóttir, 2014). Undirbúningur fyrir virka pátttöku í lýðræðispjóðfélagi var skólastjórnendum framhaldsskóla enda ekki ofarlega í huga í rannsókn Guðrúnar Ragnarsdóttur (2018) pegar spurt var um hlutverk skólans. Bent hefur verið á lægri tíðni samvinnu í starfsnámi en bóknámi hér á landi, pótt æetla mætti að pjálfun í samvinnu væri einmitt mikilvægur undirbúningur fyrir starf (Elsa Eiríksdóttir, Guðrún Ragnarsdóttir og Jón Torfi Jónasson, 2018). •að sama á við um önnur Evrópulönd (European Commission o.fl., 2017). Pannig fer starfsnám halloka fyrir bóknámi hvað varðar bjálfun nemenda í samvinnu. 
Viðhorf nemenda til hópvinnu virtust vera tvíbent í rannsókn á æskilegum námsaðstæðum (Anna Kristín Sigurðardóttir og Sigrún Harpa Magnúsdóttir, 2018). Dar forgangsröðuðu nemendahópar 12 ljósmyndum af ýmsum aðstæðum í skóla á níu reiti, raðað í fimm raðir innan í tígulmynd. prír peir efstu voru ætlaðir myndum af góðum aðstæðum til að læra („Hér er gott að læra“). Tvær myndanna vísuðu til samvinnu, önnur sýndi mannlaus hópvinnuborð en hin nemendur í hópum að vinna saman og gat pað verið hvar sem var í skólabyggingunni. Átta hópar af 17 röðuðu annarri hvorri samvinnumyndanna í einn af efstu premur reitunum.

Af framansögðu má ráđa að samvinna nemenda sé ekki áherslupáttur í vali kennara um kennsluaðferðir, prátt fyrir skýra stefnumörkun um lýðræðislega starfshætti skóla - en samvinna nemenda við úrlausn viðfangsefna í náminu hlýtur að vera mikilvægur páttur í peim.

\section{Markmið og rannsóknarspurningar}

Ljóst er að rík áhersla er á menntun til lýðræðislegrar pátttöku - nám til lýðræðis - bæði á alpjóðlegum vettvangi og í íslenskum aðalnámskrám, að aðalnámskrá framhaldsskóla meðtalinni. Par skipa lýðræðislegir náms- og kennsluhættir - nám í lýðræði - stóran sess. Pýðingarmikill liður í peim er samstarf nemenda um lausn viðfangsefna, sem hér er í brennidepli. Óljósara er aftur á móti hvernig pessari stefnumörkun er framfylgt í reynd. Takmarkaðar upplýsingar liggja fyrir um áherslu kennara í framhaldsskólum á samvinnu nemenda í kennslustundum og viðhorf nemenda til hennar, pó vísbendingar séu um að samvinna leiki ekki stórt hlutverk í skólastofum framhaldsskóla. Markmið greinarinnar er að varpa ljósi á samvinnu framhaldsskólanemenda í kennslustundum, nánar tiltekið tíðni hennar, umfang og skipulag, og viðhorf nemenda til samvinnu.

Í ljósi lýðræðisáherslna í fjölbjóðlegri stefnumörkun og námskrá framhaldsskóla, jafnt sem fræðilegrar umræðu um samvinnunám eða hópvinnu af ýmsu tagi verður hér leitað svara við eftirfarandi rannsóknarspurningum:

- Hver er tíðni og umfang samvinnu framhaldsskólanemenda í kennslustundum?

- Hvernig er skipulagi samvinnunnar háttað af hendi kennara og nemenda?

- Hvernig birtast viðhorf nemenda til samvinnu í náminu?

\section{Framkvæmd rannsóknar}

Byggt er á gögnum úr rannsókninni Starfshættir í framhaldsskólum sem fram fór í níu framhaldsskólum víðs vegar um landið, völdum með lagskiptu slembiúrtaki (sjá nánar um framkvæmd: Gerður G. Óskarsdóttir og rannsóknarhópur um starfshætti í framhaldsskólum, 2018). [1] Hér er unnið úr vettvangslýsingum og viðtölum við nemendahópa.

\section{Vettvangslýsingar og hópviðtöl við nemendur}

Unnið var úr vettvangslýsingum á 130 kennslustundum (167 klukkustundum). Pær voru frá 40 mínútum upp í um fjórar klukkustundir að lengd, en langflestar peirra (82\%) stóðu í 40 til 80 mínútur. Kennslustundir voru valdar af handahófi. Nemendum af mismunandi námsbrautum var fylgt eftir, að minnsta kosti einum nemanda eða bekk á hverju námsári í öllum skólunum, en tveimur til premur í stærri skólum og skólum með starfsnámsbrautir. Rannsakendahópurinn, alls 15 manns, skipti með sér vettvangsathugunum. Ýmist voru einn eða tveir athugendur í hverri kennslustund, einn í 73 stundum, en tveir í 57 peirra sem skráðu vettvangslýsingu sameiginlega. Stuðst var við par til gert skráningareyðublað. Lýsing á kennslustund skiptist í tvo dálka, annar fyrir pað sem kennari gerði og hinn fyrir framlag nemenda. Athugendur tilgreindu tímann yfirleitt á um fimm mínútna fresti. Rannsakendur fylgdu lýsingu sinni síðan eftir með stuttri samantekt og hugleiðingum um kennslustundina. 
Jafnframt voru greind viðtöl við 17 nemendahópa með alls 56 pátttakendum 18 ára og eldri sem buðu sig fram til pátttöku. Í hverjum hópi voru tveir til fimm nemendur. Fimm rannsakendur deildu með sér að taka viðtölin, tveir saman í sjö peirra en einn tók hin 10. Í viðtalsramma voru ekki sérstakar spurningar um samvinnu, en í upphafi viðtals ræddu og forgangsröðuðu nemendahóparnir 12 ljósmyndum af mismunandi námsaðstæðum og vísuðu tvær peirra til samvinnu (sjá Önnu Kristínu Sigurðardóttur og Sigrúnu Hörpu Magnúsdóttur, 2018; Clark, Laing, Tiplady og Woolner, 2013). Önnur myndin var af skólastofu án nemenda með fjórum hópborðum og átta stólum við hvert, en hin sýndi nemendur að vinna saman í hópum sem gátu verið hvar sem er í skólabyggingu. Út frá myndunum var rætt um viðkomandi kennsluaðferð, svo sem tíðni hennar og framkvæmd.

\section{Greining gagna og túlkun niðurstaðna}

Við greiningu vettvangslýsinganna var beitt bæði megindlegri og eigindlegri nálgun á pessi eigindlegu gögn. Til að varpa ljósi á tíðni samvinnunnar var tekinn saman fjöldi kennslustunda með einhvers konar samvinnu (megindleg nálgun). Tekið skal fram að stundum er pess getið í vettvangslýsingum að nokkrir nemendur hafi sjálfir átt frumkvæði að pví að vinna saman að verkefnum sem kennari lagði fyrir sem einstaklingsverkefni. Dær stundir voru ekki taldar með ef ekki kom fram að kennari hefði hvatt til samstarfs eða getið pess að vinna mætti saman að verkefninu. Nemendakynningar voru taldar til samvinnu ef nemendahópur undirbjó hana saman eða stóð saman að henni í kennslustund, en ekki meðtaldar ef einn nemandi kynnti í kennslustund eða sýndi myndband og allir aðrir voru áheyrendur. Umfangið var aftur á móti greint með pví að taka saman mínútufjölda sem varið var í samvinnu (megindleg nálgun). Skoðaður var munur milli skóla og námsgreina í pessum efnum. Einnig var athugað hvort ákveðnar ytri aðstæður (stærð námshópa eða bekkja og uppröðun húsgagna) hefðu áhrif á tíðni og umfang, eða með öðrum orðum að samvinna væri valin sem nálgun í náminu.

Við greiningu á skipulagi samvinnunnar út frá vettvangslýsingunum var stuðst við prískipta flokkun höfundar, en jafnframt skoðuð hópskipan, hlutverk í hópi, hópstærð, hvati til virkni og markmið samvinnu (eigindleg nálgun). Við flokkunina var að hluta til tekið mið af skilgreiningum á samvinnunámi annars vegar og ýmiss konar hópvinnu nemenda hins vegar eins og munurinn var skilgreindur hér framar. Flokkarnir urðu pessir: a) Hópvinna eða samvinnunám skipulagt af kennara og nemendur unnu síðan að lausn viðfangsefnis sameiginlega í einstökum hópum; b) Hópvinna sem kennari sagði fyrir um, en nemendur í einstökum hópum skiptu nær strax með sér verkum og unnu síðan að mestu einslega; c) Valfrjáls hópvinna par sem kennari sagði að nemendur mættu vinna saman í hópum og meirihluti nemenda kaus að gera pað.

Viðhorf nemenda voru greind út frá umræðum nemendahópanna um fyrrnefndar tvær ljósmyndir sem vísuðu til samvinnu. Dregin eru fram dæmi úr umræðunum sem póttu lýsa bæði jákvæðum og neikvæðum viðhorfum til samvinnu, auk pess sem vísað er í hugleiðingar nemenda um pá pætti samvinnu sem hér eru til umræðu, par með talin hópskipan, hlutverk í hópi, hópstærð og virkni nemenda.

Túlkun niðurstaðna tók mið af markmiði rannsóknarinnar og rannsóknarspurningum með hliðsjón af fjöllpjóðlegri stefnumörkun og ákvæðum í aðalnámskrá framhaldsskóla um lýðræðislegt samstarf.

\section{Styrkleikar og veikleikar}

Styrkleikar rannsóknarinnar felast meðal annars í pví að stuðst er bæði við vettvangslýsingar og viðtöl við nemendur og par með fæst nokkuð víð sýn á viðfangsefnið. Byggt er á mjög umfangsmiklu gagnasafni. Blanda af megindlegri og eigindlegri nálgun við greiningu vettvangslýsinganna víkkar enn frekar sjónarhornið. Höfundur tók pátt í vettvangsathugunum í öllum skólunum níu og nokkrum viðtalanna við nemendur. 
Dað kann að takmarka pessa rannsókn að samvinna nemenda var ekki í brennidepli í gagnaöflun. Markmiðið með vettvangsathugunum og viðtölum við nemendur í rannsókninni á starfsháttum í framhaldsskólum (sem pessi athugun er hluti af) var að safna efni um nám og kennslu almennt (Gerður G. Óskarsdóttir og rannsóknarhópur um starfshætti í framhaldsskólum, 2018). Dar af leiðandi eru lýsingar á samvinnu í vettvangslýsingum og umræður nemenda um samvinnu misítarlegar. Engu að síður gefa niðurstöður allskýra mynd af tíðni, umfangi og skipulagi samvinnu nemenda í kennslustundum í framhaldsskólum og viðhorfum nemenda - sem ætlunin var að varpa ljósi á.

\section{Niðurstöður}

Í pessum kafla verður í fyrsta lagi greint frá niðurstöðum um tíðni og umfang samvinnu framhaldsskólanemenda í kennslustundum á grunni vettvangslýsinga. Tilvísunum í nemendaviðtöl er fléttað inn í umfjöllunina. Í öðru lagi er lýst jákvæðum og neikvæðum viðhorfum nemenda til samvinnu. Loks er fjallað um skipulag samvinnunnar af hendi kennara og nemenda og byggt bæði á vettvangslýsingum og nemendaviðtölum.

\section{Tídni og umfang samvinnu nemenda}

Hér er lýst niðurstöðum um tíðni og umfang samvinnu. Borið er saman umfang samvinnu í byrjenda- og framhaldsáföngum. Einnig er greint er frá mun á milli skóla og námsgreina. Loks er sjónum beint að hugsanlegum áhrifum nemendafjölda í námshópi eða uppröđun húsgagna á tíðnina.

Niðurstöður um tíðni samvinnu leiddu í ljós að kennari skipulagði samstarf nemenda eða mæltist til að nemendur ynnu saman í pörum eða hópum með einhverjum hætti í 47 kennslustundum af peim 130 sem fylgst var með (36\%). Heildarlengd kennslustundanna var mismunandi, allt frá 40 mínútum upp í tæplega tvær klukkustundir, en meirihluti peirra (62\%) stóð í 60-80 mínútur. Paravinna taldist vera í um priðjungi kennslustunda með einhverja samvinnu. Degar spurt var í nemendaviðtölunum um tíðni samvinnu voru svörin allt frá pví að einn sagði: „Nú eru hópverkefni upp á hvern einasta dag“ yfir í að annar sagði hreint út: „Mjög sjaldan“ og bætt var við: „Myndi segja ... einu sinni á önn, sko, í [hverri grein].“ Ekki liggur reyndar ljóst fyrir hvaða merkingu nemendur lögðu í hugtakið samvinnu.

Til að meta aftur á móti umfangið var tekinn saman fjöldi mínútna sem fór í samvinnu í kennslustundunum - sem segir meira um möguleika nemenda á bjálfun í samvinnu en fjöldi stunda með samvinnu. Í ljós kom að einhvers konar samvinna átti sér stað í um 17\% heildarkennslutímans sem fylgst var með (alls í um 28 klukkustundir af 167). Mjög misjafnt var hve lengi samvinnan varði, allt frá tíu mínútum upp í að öll kennslustundin var nýtt í samvinnu.

Degar heildarumfang samvinnu í byrjendaáföngum (tveir fyrstu í námsgrein) og framhaldsáföngum var borið saman kom ekki fram munur. Pannig jókst pjálfun í samvinnu ekki pegar leið á námið.

\section{Munur á umfangi milli skóla}

Munur kom fram á umfangi samvinnu milli skóla. Sjö skólar af níu voru nærri 17\% meðaltalinu pegar umfangið var greint, en í peim var $12-22 \%$ heildarkennslutímans varið í einhvers konar samvinnu. Tveir skólar skáru sig greinilega úr. Annar var með talsvert umfangsmeiri samvinnu en aðrir og hinn með mun minni. Í peim fyrrnefnda unnu nemendur saman í hópum í 34\% heildartímans sem fylgst var með. Afturá móti unnu nemendur samaní aðeins um 3\% heildartímans í hinum síðarnefnda. Dar voru einstaklingsverkefni ráðandi. Svo rýr hlutur samvinnu nemenda vekur óneitanlega athygli. Degar nemendahópur í fyrrnefnda skólanum var spurður hvaða kennsluaðferðir væru algengastar, kom svarið: „Hópvinna örugglega.“ Sambærilegt svar kom ekki í hinum skólunum. 


\section{Munur á tídni milli námsgreina}

Dreifing á tíđni samvinnu milli sjö námsgreinaflokka (1́ 47 kennslustundum) var nokkuð mikil, eins og sjá má í töflu 1 (annar dálkur). En hafa verður í huga að fjöldi stunda sem fylgst var með var mismunandi milli námsgreinaflokkanna (tafla 1, tölur innan sviga í priðja dálki). Degar tekið var saman hlutfall stunda með samvinnu af heildarstundum í viðkomandi greinaflokki í gagnasafninu kom í ljós að samvinna kom hlutfallslega oftast fyrir innan íslensku (í 7 af 12 stundum eða 58\%) og erlendra tungumála (í 11 af 20 stundum eða 55\%) (tafla 1, priðji dálkur). Hópvinna með einhverjum hætti fór fram í yfir helmingi kennslustundanna sem fylgst var með í pessum tveimur námsgreinum. Tíðni samvinnu var lægst innan flokks félags- og hugvísindagreina (í 6 af 29 stundum eða $21 \%)$.

Tafla 1. Tíðni: Fjöldi kennslustunda með samvinnu í einstökum námsgreinaflokkum.

\begin{tabular}{lcc}
\hline Námsgreinaflokkar & $\begin{array}{c}\text { Hlutfall námsgreinaflokks af } \\
\text { heildarfjölda kennslustunda með } \\
\text { samvinnu (alls 47; fjöldi kennslu- } \\
\text { stunda í námsgreinaflokki innan sviga) }\end{array}$ & $\begin{array}{c}\text { Hlutfall kennslustunda með } \\
\text { samvinnu af heildarfjölda } \\
\text { kennslustunda í viðkomandi } \\
\text { námsgreinaflokki }\end{array}$ \\
\hline Erlend tungumál & $23 \%(11$ st.) & $55 \%$ (11 st. af 20) \\
Félags- og hugvísindagreinar & $13 \%$ (6 st.) & $21 \%$ (6 st. af 29) \\
Iðn- og starfsnámsgreinar & $11 \%(5$ st.) & $28 \%$ (5 st. af 18) \\
Íslenska & $15 \%(7$ st.) & $58 \%$ (7 st. af 12) \\
Náttúruvísindagreinar & $13 \%(6$ st.) & $33 \%$ (6 st. af 18) \\
Stærðfræði & $11 \%(5$ st.) & $36 \%$ (5 st. af 14) \\
Annað (meðal annars ípróttir, \\
hönnun, listir, tölvufræði og \\
pverfaglegt nám) \\
Alls
\end{tabular}

\section{Meðalfjöldi í námshópi og uppröðun húsgagna}

Ekki kom fram marktækur munur á meðalfjölda viðstaddra nemenda í kennslustundum með samvinnu (17 nemendur) og öðrum kennslustundum (15 nemendur). Pannig hafði nemendafjöldi í námshópi, pað er bekk eða áfanga, ekki áhrif á pað hvort samvinna ætti sér stað eða ekki.

Uppröðun húsgagna hafði minni áhrif en ætla mátti (sjá töflu 2). Borðum og stólum var stillt upp í raðir (44\%) eða „u“ (13\%) í 57\% kennslustunda með samvinnu, en nokkru oftar í stundum án samvinnu eða í 75\% tilfella (tafla 2, priðji og fjórði dálkur). Svo var að sjá sem slík uppröðun hindraði ekki samvinnu. Nemendur færðu stóla til eða sneru sér við í sætum sínum. Hópuppröðun borða virtist aftur á móti vera hvati til samvinnu. Pannig uppröðun var í um $32 \%$ stunda með samvinnu, en $17 \%$ stunda par sem engin samvinna var, eins og sjá má í töflu 2 (fimmti dálkur).

Tafla 2. Uppröðun húsgagna.

\begin{tabular}{lcccccc}
\hline & $\begin{array}{c}\text { Alls } \\
\text { Samvinna }\end{array}$ & $\begin{array}{c}\text { Borð og stólar } \\
\text { íröðum pvert } \\
\text { yfir stofu }\end{array}$ & $\begin{array}{c}\text { Borðum } \\
\text { raðað i } \\
\text { „““ }\end{array}$ & $\begin{array}{c}\text { Hópuppröðun } \\
\text { borða }\end{array}$ & $\begin{array}{c}\text { Annað } \\
\text { (verkstæði, } \\
\text { ípróttir) }\end{array}$ & $\begin{array}{c}\text { Hlutfall } \\
\text { alls }\end{array}$ \\
\hline Ekki samvinna & 47 & $21(44 \%)$ & $6(13 \%)$ & $15(32 \%)$ & $5(11 \%)$ & $(100 \%)$ \\
Kennslustundir alls & 83 & $56(68 \%)$ & $6(7 \%)$ & $14(17 \%)$ & $7(8 \%)$ & $(100 \%)$ \\
\hline & 130 & $77(59 \%)$ & $12(9 \%)$ & $29(23 \%)$ & $12(9 \%)$ & $(100 \%)$ \\
\hline
\end{tabular}


Dessar niðurstöður um tíðni og umfang samvinnu nemenda draga skýrt fram að samvinna nemenda skipaði ekki stóran sess í kennslustundunum 130 sem fylgst var með. Einhvers konar samvinna var viðhöfð í rúmlega priðjungi (36\%) peirra, en tók aðeins um 17\% heildartímans. Mikil frávik í tveimur skólanna vöktu athygli. Ekki kom fram munur á umfangi milli byrjendaog framhaldsáfanga. Munur var á tíðni milli námsgreina. Fjöldi í nemendahópi hafði engin áhrif í pessum efnum og uppröðun húsgagna virtist ekki hafa afgerandi áhrif á ákvörðun kennara um að ætla nemendum að vinna saman í hópum.

\section{Viðhorf nemenda til samvinnu - ýmist jákvæð eða neikvæð}

Samvinna nemenda var til umræðu í nemendaviðtölunum út frá tveimur myndum sem vísuðu til samstarfs í náminu, eins og komið hefur fram. Leitað var eftir almennum viðhorfum til samvinnu. Mjög misjafnt var hvernig nemendum líkaði að vinna með öðrum í hópi. Deim féll ýmist mjög vel við hópvinnu, sögðu hana ,auðvelda verkið“ eða sögðust ekki pola hana. Innan sama viðmælendahóps heyrðust gjarnan bæði jákvæðar og neikvæðar raddir, svo viðhorfin virtust almennt ekki vera bundin við skóla. Eins og margir nemendur sögðu fer tíðni og umfang samvinnu gjarnan eftir kennurum.

Nemendahóparnir voru spurðir hvernig peim fyndist best að læra út frá myndunum 12 sem sýndu mismunandi námsaðstæður og raða átti í níu reiti innan tíguls, eins og fyrr segir (sjá kafla um framkvæmd). Átta hópar af 17 röðuðu annarri hvorri hópmyndanna í einn af premur efstu reitunum, sem ætlaðir voru fyrir góðar aðstæður (Anna Kristín Sigurðardóttir og Sigrún Harpa Magnúsdóttir, 2018). Ætla má að margs konar og mismunandi samvinna hafi verið í hugum nemenda við forgangsröðunina og í umræðunum sem fylgdu (sbr. til dæmis skilgreiningar á samvinnu hér framar eða prískipta flokkun á skipulagi á mynd 3 hér síðar).

Degar spurt var nánar um bestu kringumstæður til að læra kom í einum hópanna svarið: „Í hópvinnu, par sem maður getur talað mikið.“ Á öðrum stað: „Mér finnst pað eiginlega bara bestu aðstæðurnar, hópvinna." Pá var spurt hvernig pau lærðu hvert af öðru í hópunum. Á einum stað kom svarið:

Sérstaklega pegar við erum í til dæmis félagsfræði, pá erum við að lesa um ákveðna hluti, við gerðum verkefni par sem við máttum velja nokkra hluti ... Síðan vorum við sett í hópa, pá vorum við öll með sitt hvora hluti og vorum að tala um pað. Dannig að pá lærum við af hvert öðru.

Frekari rök fyrir gildi samvinnuverkefna voru að fólk væri gott á mismunandi sviðum og lærði pví hvert af öðru. Einnig var bent á að notalegt væri að sitja saman pótt ekki færi fram samvinna, en möguleiki væri á að hjálpast að: „Ef maður er ekki öruggur, pá er náttúrulega gott að geta spurt næsta mann aðeins.“

Aðrir voru á öndverðum meiði, töldu sig læra lítið af hópvinnu og líkaði hún illa. Í einum nemendahópi kom svarið: „Mér finnst allavega ógeðslega leiðinlegt að vinna í hópvinnu, svona yfirleitt“ og annar tók undir: „Mér líka.“ Viðmælanda fannst ókostur að annar í hópnum vissi eitthvað og pá skráði hann pað eftir honum í staðinn fyrir að pæla í pví sjálfur. Annar viðurkenndi að finnast bara truflandi að vera með öðrum.

Hér gæti ólík reynsla nemendanna af hópstarfi hafa mótað viðhorf peirra, jákvæð reynsla skýrt jákvætt viðhorf og öfugt. Ýmsir pættir sem snerta skipulag samvinnu bárust í tal í nemendahópunum pegar rætt var um fyrrnefndar samvinnumyndir, án pess að spurt væri um pá sérstaklega. Umfjöllun par um er fléttað inn í næsta kafla um skipulag á samvinnu nemenda.

\section{Skipulag samvinnu nemenda}

Í pessum kafla verður skipulagi samvinnu nemenda í kennslustundum lýst á grunni bæði vettvangslýsinga og viðtala við nemendahópa. Fyrst er skipulagið greint í prjá flokka eftir pví 
hvernig til samstarfsins er stofnað af kennara, eins og fyrr segir. Pá er fjallað um hópskipan, hlutverk í hópi og hópstærð. Allir pessi pættir geta síðan haft áhrif á virkni pátttakenda í samvinnunni, sem næst er tekin fyrir. Pannig er litið svo á að viðleitni kennara og nemenda sjálfra til að stuðla að virkni allra sé hluti af skipulaginu. Dví næst er ræett um markmiðssetningu og endurgjöf sem liði í skipulagi samvinnuverkefna. Loks er til umfjöllunar greining á milli samvinnunáms og hópvinnu á grunni niðurstaðnanna.

\section{Drenns konar skipulag}

Í töflu 3 er skipulag samvinnu greint í prjá flokka á grunni vettvangslýsinga, með hliðsjón af pví hvernig til hennar var stofnað af kennara. Í fyrsta dálki er lýst einkennum flokkanna priggja. Í öðrum dálki er tiltekinn fjöldi kennslustunda með samvinnu í viðkomandi flokki (tíðni). Loks er í priðja dálki greint frá hlutfalli hvers flokks af kennslustundunum 47 með einhvers konar samstarf.

Tafla 3. Skipulag á samvinnu nemenda greint í prjá flokka og tíðni peirra.

\begin{tabular}{lcc}
\hline Prenns konar skipulag & Fjöldi stunda (tíðni) $\%$ af 47 stundum \\
\hline $\begin{array}{l}\text { a) Hópvinna eða samvinnunám skipulagt af kennara og } \\
\text { nemendur unnu síðan að lausn viðfangsefnis } \\
\text { sameiginlega í einstökum hópum }\end{array}$ & 27 & $59 \%$ \\
b) Hópvinna sem kennari sagði fyrir um, en nemendur í \\
$\begin{array}{l}\text { einstökum hópum skiptu nær strax með sér verkum og } \\
\text { unnu síðan að mestu einslega, samvinna í raun í } \\
\text { algeru lágmarki (oft lýst pögn í kennslustofu) }\end{array}$ & 12 & $25 \%$ \\
$\begin{array}{l}\text { c) Valfrjáls hópvinna par sem kennari sagði að nemendur } \\
\text { mættu vinna saman í hópum og meirihluti nemenda } \\
\text { kaus að gera pað }\end{array}$ & & \\
\hline Alls kennslustundir par sem samvinna fór fram & 8 & $16 \%$ \\
\hline
\end{tabular}

Flokkur a: Kennslustundir par sem kennari skipulagði hópvinnu eða samvinnunám og nemendur unnu saman að viðkomandi verkefni voru 59\% af heildarfjölda kennslustunda með samvinnu. Sem dæmi um slíkt fyrirkomulag má nefna kennslustundir í erlendum tungumálum. Nemendapör fengu í hendur umslög með sex myndum af fólki við ýmiss konar iðju og áttu í sameiningu að mynda setningar á markmálinu um viðfangsefni fólksins. Í öðru tilviki svöruðu nemendur skilaboðum í síma á viðkomandi tungumáli og í pví priðja töluðu nemendur saman í breytilegum pörum um atburði helgarinnar (sjá um sérstaka greiningu á samvinnunámi hér síðar).

Flokkur b: Nemendur voru ekki alltaf að vinna saman í samvinnuverkefnum eða í 25\% samvinnustundanna. Kennari sagði fyrir um hópvinnu án frekari útlistunar á framkvæmd hennar. Nemendur skiptu nær strax með sér verkum og hver og einn fór að vinna að sínu. Gjarnan var skrád pögn í kennslustofunni. Í lokin lögðu nemendur ef til vill sitt efni í sameiginlegan texta eða kynningu, stundum í kjölfar stuttra samræðna innan hópsins. Рað átti til dæmis við um líffræðitíma par sem nemendur áttu að vinna í pörum að fjórum viðfangsefnum með mismunandi afurð, svo sem glærukynningu, myndbandi, spurningablaði eða veggspjaldi. Nemendur unnu pegjandi hver fyrir sig, að pví er virtist við að taka texta úr greinum og færa í annað form. Parna reyndi vart á samvinnu. Dví er ekki par með sagt að nemendur bjálfist í samstarfi í öllum gerðum samvinnuverkefna. Í máli nemenda var að heyra að petta væri nokkuð algengt, eins og einn orðaði pað: „En einhvern veginn finnst mér alltaf hópvinna verða að „einn einhvers staðar“ ... Hópvinna verður alltaf einhvern veginn sko einstaklings og svo kemur hópurinn saman." Annar bætti við: „Баð er kannski planað, hópurinn planar saman og síðan bara einstaklingarnir gera ákveðið mikið.“ Nemendur vinna mikið til einir bótt kennsluaðferðin sé flokkuð sem samvinna.

Flokkur c: Driðji flokkurinn lýsir hópvinnu par sem kennari segir að nemendur megi vinna saman og meirihlutinn ákveður að gera pað til að auðvelda verk. Pannig flokkuðust 16\% 
samvinnustundanna. Í iðnfræði í ákveðinni iðngrein voru nemendur til dæmis að vinna einstaklingsverkefni sem meðal annars snerist um hugtök, eyðufyllingar og rétt/rangt-spurningar, en kennarinn bauð nemendum að leysa pau í samstarfi - sem nemendur tóku vel og röðuðu sér strax í hópa og unnu saman.

\section{Hópskipan, hlutverk í hópi og hópstarð}

Mikilvægir pættir í skipulagi samvinnu eru fyrirkomulag á vali í hópa, hlutverk hvers og eins í hópnum og hópstærð.

Skipan í hópa var langoftast í höndum nemenda sjálfra, eða í vel yfir tveimur priðju tilfella par sem samvinnu var lýst í vettvangslýsingunum. Á einum stað tók rannsakandi fram að hópmyndanir hefðu greinilega farið eftir vinatengslum. Kennari greip stundum inn í valið, lagði lokahönd á röðunina ef einhverjir stóðu eftir eða bað nemanda að vinna með öðrum sem varð stakur. Pannig gerði kennarinn tilraun til að vinna gegn valdaójafnvægi eða koma í veg fyrir að nemandi yrði útundan, en athygli vekur hve sjaldan pað gerðist. Ef kennari raðaði í hópa (í priðjungi tilfella) var pað gjarnan gert með pví að telja í hópana, en nemendur drógu einnig spil eða miða með ákveðnu verkefni. Með pessu móti kom kennarinn í veg fyrir að einhverjir stæðu einir eftir. Eitt dæmi var um að kennari hafði hugsað samsetningu hópa fyrir fram. Degar nemendur komu í stofu voru miðar á borðum með nöfnum peirra sem skyldu sitja saman. Ef til vill hafði kennarinn 1 uppröðun sinni hugað að einhvers konar jafnvægi innan hópa og milli hópa.

Yfirleitt voru nemendurnir sammála um að best gengi pegar pau röđuðu sér sjálfí hópa í stað pess að kennarinn ákvæði hverjir skyldu vinna saman. Pá skapaðist betri starfsandi og meiri líkur á að samvinna yrði í hópnum, var gjarnan viðkvæðið. Sum lögðu sérstaklega upp úr pví að pekkja samstarfsfólk sitt. Skapast gæeti pvingað andrúmsloft „,pegar maður lendir með einhverjum sem ... maður talar ekki einu sinni við svona, dagsdaglega“ og pá væri erfitt að vinna saman utan skólans. Ein var mjög afgerandi og sagði:

Ég persónulega filla ekki hópvinnu pegar ég er sett í hóp með einhverju fólki sem ég pekki ekki neitt, eða ... ef pað er stór hópur pá er ég mikið ólíklegri til pess að ... taka pátt og ... pað er líka misjafnt eftir fólki, sumum finnst ópægilegt að tala við fólk sem pú pekkir ekki.

Pó heyrðist einnig pað álit að allir hefðu gott af pví að vinna með ólíku fólki, kynnast nýjum aðilum, og koma pyrfti í veg fyrir að einhverjir yrðu utanveltu. Einn sagðist reyndar sækjast eftir mannlegum samskiptum og væri pví sama um hverjum hann ynni með, „bara svo lengi sem hann er ekki dónalegur eða eitthvað svoleiðis“. Í öđrum hópi var bent á að kannski væri líka markmiðið með vinnu í hópum að allir gætu unnið með hverjum sem væri og að fólk kynntist betur. Nefnt var að stundum gripi kennari inn í valið til að blanda nemendum saman, eins og einnig kom fram í vettvangslýsingum. Til dæmis var sagt frá kennara sem sendi viðkomandi í annan hóp og öðrum sem vildi fyrirbyggja að aðili yrði útundan.

Önnur rök fyrir vali nemenda sjálfra í hópa var að einstaklingar á svipuðu róli í náminu veldust saman, pau vildu vinna með jafningjum, eins og pað var orðað: „Баð er skelfilegt að vera með einhverjum sem er miklu klárari en maður og skelfilegt að vera með einhverjum sem er langt á eftir." Pó var nefnt að unnt væri að læra af peim sem betur stæðu. Að baki sterkri áherslu á að nemendur skipuðu sér sjálf í hópa bjó ef til vill löngun til að hafa einhverja stjórn á aðstæðum, vera með í skipulagi námsins.

Hlutverkumvarskiptfyrirframíhópunumíaðeinsfáumtilfellum, samkvæmtvettvangslýsingunum, til dæmis að vera ritari eða sá sem kynnti niðurstöður í lokin, ef við átti. Kennarinn spurði pó stundum hver ætlaði að rita eða kynna. Dæmi um hlutverkaskipan kemur fram í tilvísun í orð nemanda hér framar um félagsfræðitíma par sem nemandi sagði að pau hefðu mátt ,velja nokkra hluti“ og síðan öll verið „,með sitt hvora hluti og voru... að tala um pað“ í hópum (inntaksleg 
hlutverk). Í enskutíma sagði kennari að hver og einn skyldi velja sér hlutverk innan hvers priggja manna hóps: einn drifi verkið áfram, væri hvetjari, annar tímavörður og sá priðji talsmaður (félagsleg hlutverk).

Stærð hópa í samvinnuverkefnum var breytileg samkvæmt vettvangslýsingunum, frá tveimur upp í sex pátttakendur, en algengast virtist vera að í hverjum hópi, utan paravinnu, væru prír til fjórir. Nemendur nefndu að hópar mættu helst ekki vera fjölmennari en prír, eins og einn viðmælandi orðaði pað: „Allt í lagi ef pað eru svona prír í hópi, ef pað er meira en pað ... pá eru alltaf einhverjir sem gera ekki neitt." Greina má af orðum nemandans að petta mat hafi ekki byggst á samvinnunámi eða hópvinnu par sem allir pátttakendur hafa ákveðið hlutverk og einstaklingar verða pví ekki svo glatt laumufarpegar.

\section{Virkni i hópi - laumufarpegar og spjall}

Mismikil pátttaka einstaklinga í samvinnuverkefnum skapast trúlega oft af pví að hópstarfið sjálft er lítið skipulagt fyrir fram, hvorki af kennara sem liður í undirbúningi kennslustundar né nemendum sjálfum í upphafi samstarfsverkefnis. Laumufarpegavandinn virtist vera nemendum ofarlega í huga og var alloft skýring peirra á neikvæðu viðhorfi til hópvinnu: „Einn sem gerir mest og hinir gera ekki neitt“ eða „,pað er yfirleitt einn sem endar á bví að gera hópverkefnin“. Sú skýring var einnig gefin , að einhver einn segist ætla að gera allt en svo gerir hann ekki neitt og ... pað bitnar á öllum hinum“. Og annar bætti við: „Еða pá að einn parf að gera allt.“ Verra pótti að allir fengju samt „kredit“ fyrir verkefnið. Pegar rætt var um nemendakynningar kom eftirfarandi lýsing:

Já, svo sér maður pað sérstaklega í, ef petta eru einhver verkefni sem á að flytja ... pú veist svona power point eða eitthvað ... pá sést alveg hverjir gerðu verkefnið af pví hinir eru bara horfandi á skjáinn og lesa upp og svo eru peir kannski sem ... getur talað án pess að horfa á skjáinn.

Sum hikuðu ekki við að lýsa yfir pví að pau sjálf gerðu allt í samvinnuverkefnum, með öðrum orðum tækju sjálf stjórnina í sínar hendur: „Ég er yfirleitt manneskjan sem geri hlutina í hópum ... Ég vil gera hlutina sjálf ... vinna mitt, mín verkefni sjálf.“ Pá var annar nemandi spurður um sinn hlut, hvort hann gerði allt eða væri sá sem slyppi:

Ég reyni að fara milliveginn og reyni að drífa hópinn allavega áfram, saman ... pað er eiginlega alltaf mjög erfitt pví að pað eru alltaf einhverjir ... sem að hanga inni á Facebook, í símanum og eru bara að gera ekki neitt.

Loks var innlegg eins: „Ég hef verið á báđum endunum á pessu priki. Ég hef verið sá sem gerir ekki rassgat og líka sá sem gerir petta bara.“

Annar vandi sem tengist mismiklu vinnuframlagi var sú árátta margra að fara bara að „spjalla“ í hópnum, að sögn nemanda, og pví yrði viðkomandi ekki mikið úr verki. Öðrum fannst pað afsakanlegt og spurði: „Hvernig hefur pú farið í hópa, unnið svona og ekki dottið í spjall?“ Og fékk svarið: ,Ja, ég hef alveg gert pað.“

Viðmælendum virtist ekki koma til hugar að kennari, hópfélagar sjálfir eða kennari og nemendur í sameiningu gætu hugsanlega með frekara skipulagi komið í veg fyrir misvægi í vinnuframlagi eða mismikla virkni.

\section{Markmið, tilgangur og endurgjöf}

Markmið og tilgangur samvinnuverkefna eða endurgjöf kennara bar varla á góma í vettvangslýsingunum eða viðtölunum, en margir fræðimenn leggja áherslu á að skýrt markmið skerpi á áhuga og virkni nemenda, ásamt endurgjöf á grunni pess (sbr. hér framar). Dæmi var um 
samfélagslegan tilgang samstarfs pegar kennari sagði: „Уað má vinna einn, en best er að vera í hópi, pá lærir maður að vinna með öðrum." Svo var að sjá sem nokkurn veginn jafnmikið væri um viðfangsefni sem höfðu pað almenna markmið að afla pekkingar og verkefni sem virtust gefa nemendum tækifæri til að leita ópekktra lausna, pað er sýna frumkvæði eða vera skapandi. Ekki kom fram í lýsingunum hvort útkoma samvinnuverkefna í heild var metin eða framlag og framfarir hvers og eins. Dæmi voru um að einstakir nemendur í hópi skiluðu niðurstöðu sinni til kennara, sem bendir til mats á framlagi einstaklinga til hópstarfsins.

\section{Skipulagt samvinnunám eða ýmiss konar hópvinna}

Erfitt er að meta í hvaða tilvikum var um formlegt samvinnunám að ræða par sem nánari upplýsingar skortir. En í örfáum tilfellum valdi kennari í hópa og skipaði nemendum í hlutverk, sem hvort tveggja er talið til einkenna samvinnunáms. Nokkrir nemendur gátu pess að peim pætti miður hve framlag hvers og eins í hópi gat verið mismikið - sem bendir til að pau hafi ekki verið vön skipulegu samvinnunámi par sem allir hafa sitt hlutverk. Önnur einkenni samvinnunáms eru skýrt markmið vinnunnar og umbun til alls hópsins. Pessir pættir voru vart til umfjöllunar í vettvangslýsingum eða nemendaviðtölum. Á grunni pessara niðurstaðna má ætla að samvinnunám, eins og pað hefur verið skilgreint (sjá hér framar), hafi verið mjög sjaldgæft og í yfirgnæfandi fjölda tilfella hafi verið um ýmiss konar óformlegri hópvinnu að ræða.

Í stuttu máli virtust kennarar ekki leggja mikla áherslu á samvinnu nemenda miðað við tíðni hennar (kom fyrir í 36\% heildarfjölda kennslustundanna sem fylgst var með) og umfang (17\% af heildartíma kennslustundanna sem fylgst var með), prátt fyrir áherslu námskrár á pjálfun í lýðræðislegu samstarfi. Munur á milli skóla var raunar talsverður og nokkur milli námsgreina. Í um fjórðungi kennslustunda par sem kennari lagði fyrir samvinnuverkefni unnu nemendur mikið til einslega að viðkomandi viðfangsefni og pví er spurning að hve miklu leyti var um samvinnu að ræða. Skipan í hópa, verkaskipting innan hópa eða áhersla á pátttöku allra virtist reyndar ekki almennt vera liður í undirbúningi kennara fyrir samvinnu nemenda. Loks var ekki að sjá að nemendur kæmu að undirbúningi eða skipulagi samvinnuverkefna og peim datt ekki í hug að nefna mögulega pátttöku sína parí - sem er mikilvægur liður í lýðræðislegum vinnubrögðum.

\section{Samantekt og umræða}

Áherslur á lýðræðislega starfshætti skóla í fjölpjóðlegri stefnumörkun, svo sem frá Evrópuráðinu, Evrópusambandinu og í Barnasáttmálanum, sem endurspeglast síðan í námskrá framhaldsskóla, voru hvatinn að pessari grein. Markmiðið var að varpa ljósi á einn lykilpátt lýðræðislegra kennsluhátta, samvinnu nemenda. Til skoðunar var tíðni, umfang og skipulag samvinnu framhaldsskólanemenda í kennslustundum og viðhorf peirra til ýmissa pátta hennar. Pá meginályktun má draga af niðurstöðum að viðleitni framhaldsskólanna til að mæta tilmælum aðalnámskrár um pjálfun í lýðræðislegu samstarfi nemenda við lausn viðfangsefna námsins sé veikburða. Dótt hér sé dregið fram mikilvægi samvinnu nemenda er ekki litið fram hjá pví að nemendur purfa tilbreytingu og einstaklingsnám í margvíslegri mynd hefur ekki síður gildi (Ingvar Sigurgeirsson, 2013).

\section{Samvinna ekki í brennidepli - munur milli námsgreina og skóla}

Spurt var um tíðni og umfang samvinnu nemenda í kennslustundum. Með pví var ætlunin að draga fram áherslu skólanna á vinnubrögð sem eru mikilvægur hluti lýðræðislegra námsog kennsluhátta eða „náms í lýðræði“ - sem er síðan liður í uppeldi til lýðræðislegar pátttöku eða „námi til lýðræðis“ (Dewey, 1916/1966; Evrópuráðið, 2010; Maitles og Gilchrist, 2005; Wolfgang Edelstein, 2010). En hafa verður í huga að samstarf í hópi er ekki alltaf lýðræðislegt, 
pótt pað ætti að sverja sig í pá átt.

Niðurstöður um tíðni leiddu í ljós að nemendur unnu saman í pörum eða hópum í rúmlega priðjungi kennslustundanna sem fylgst var með (36\%). Munur var að vísu á námsgreinum (tafla 1). Í íslensku og erlendum tungumálum fór samvinna fram í vel yfir helmingi kennslustundanna sem fylgst var með í viðkomandi námsgreinaflokki. Athygli vakti að fjöldi í námshópi eða bekk hafði ekki áhrif á tíðni og uppröðun húsgagna í skólastofum (tafla 2) leit ekki út fyrir að vera afgerandi í peim efnum.

Degar aftur á móti umfangið var metið til að fá fram tímann sem varið var til pjálfunar í samvinnu kom í ljós að aðeins í 17\% heildartímans (mælt í mínútum) fór fram einhvers konar samstarf. Detta verður að teljast lágt hlutfall miðað við áherslu í námskrá og vekur umhugsun um tækifæri nemenda til pjálfunar og reynslu af lýðræðislegu samstarfi. Raunar er petta nokkuð lengri tími en rannsóknir á fyrsta ári í reykvískum framhaldsskólum (Gerður G. Óskarsdóttir, 2012) og íslenskukennslu í framhaldsskólum (Svanhildur Kr. Sverrisdóttir, 2014) leiddu í ljós. Skýringin á hærra hlutfalli nú virðist ekki vera sú að samvinna aukist pegar ofar dregur í námi par sem ekki kom fram munur á byrjenda- og framhaldsáföngum. Trúlega er skýringin frekar sú að hér komi fram munur á milli skóla og ólík kennsluháttamenning (sbr. Goodlad, 2004).

Allnokkur samsvörun var í umfangi samvinnu milli sjö af skólunum níu. Dar var um 12-22\% kennslutímans varið í samstarf. En tveir skólar skáru sig úr. Í öđrum peirra fór samvinna aðeins fram í um 3\% heildartímans, sem jaðrar við vanrækslu á pjálfun nemenda í samstarfi samkvæmt anda námskrár. Í hinum skólanum, par sem samvinna var umfangsmest, fór hún aftur á móti fram í yfir priðjungi heildartímans sem fylgst var með og dreifðist á námsgreinar. Svör nemenda í pessum skóla um að samvinna væri par ein algengasta kennsluaðferðin studdu niðurstöðuna. Sérstaða skólans gæti bent til pess að par hafi verið mörkuð stefna um pjálfun nemenda í samvinnu og kennarahópurinn verið samstíga par um. Dá vaknar óneitanlega sú spurning hvernig sú stefnumörkun stenst tímans tönn. Minnt er á að tilraunir til breytinga á skólastarfi eiga gjarnan stuttan líftíma (Tyack og Cuban, 1995). Slavin (2008) hefur reyndar bent á að próunarstarf í pessum efnum endist frekar ef pað nær til alls skólans, viðleitni einstakra kennara dugi skammt. En fram hjá pví verður ekki litið að hlutverk hvers kennara er að skapa skilyrði sem stuðla að samstarfi, eins og Dewey undirstrikaði (1938/2000). Fróðlegt verður að fylgjast með próuninni - sem er efni í aðra rannsókn.

Að pessu sögðu liggur í loftinu spurningin um pað hve hátt hlutfall samvinnunnar ætti að vera af heildarkennslutíma til að uppfylla áherslur námskrár. Er til dæmis hæfilegt að pað sé priðjungur eða ætti pað að vera talsvert hærra eða jafnvel lægra? Deirri spurningu verður látið ósvarað hér. Aftur á móti er ljóst að ekki er sama hvernig pessum tíma er varið, par skiptir skipulagið og vinnubrögðin meginmáli.

\section{Skipulag samvinnu ekki paulhugsað}

Annarri rannsóknarspurningunni um skipulag samvinnu má svara í stuttu máli með pví að pað var yfirleitt ekki paulhugsað fyrir fram, hvorki af kennara né nemendum. Atriði í vettvangslýsingum og reynsla nemenda af samvinnuverkefnum leiddu til pessarar niðurstöðu. Ef til vill gengu kennararnir út frá pví að nemendur væru pjálfaðri í sjálfstæðri samvinnu en raun bar vitni, og treystu peim til að skipuleggja hana (Bruffee, 1995; Panitz, 1999). Flókið getur verið að ætla nemendum að vinna saman á markvissan hátt og margar leiðir eru í boði (Davidson og Major, 2014). Ýmis ljón eru á veginum, auk pess sem samvinna krefst trúlega meira af nemendum en aðrar aðferðir í námi og kennslu - og pað getur skapað andstöðu (Johnson, Johnson og Smith, 1998).

Skipulag samvinnu var greint í prjá grófa flokka (tafla 3). Nemendur unnu saman að einhverju marki í vel yfir helmingi samvinnustundanna (59\%; a-flokkur í töflu 3). Athyglisvert var aftur á 
móti að í um fjórðungi kennslustunda með samvinnu voru nemendur í raun ekki að vinna saman, heldur skiptu strax með sér verkum og unnu hver fyrir sig (25\%; b-flokkur í töflu 3). Ástæðan gat í sumum tilvikum verið að kennarinn ætlaðist til að hver og einn skilaði sinni afurð í lokin, sem hugsanlega hvatti til einstaklingsvinnu. Önnur skýring er að nemendur kunni hreinlega ekki að vinna saman og nýta sér stuðning og mismunandi kunnáttu, færni eða viðhorf hver annars. Loks geta einhvers konar samkeppnissjónarmið ráðið för. Einstaklingar hafi ekki trú á að samvinna fleyti peim áfram í náminu eða vilji ekki deila kunnáttu sinni og hæfni með öðrum, viðhorf sem eru óneitanlega ekki í anda lýðræðis (Ólafur Páll Jónsson og Póra Björg Sigurðardóttir, 2012). Reyndar var nokkuð um að nemendur tækju pví vel pegar kennari sagði að pau mættu vinna saman í hópum (16\%; c-flokkur í töflu 3). Að baki lá pá væntanlega sú trú nemenda að með pví móti gengi verkið betur, pau fengju meira út úr pví eða pau töldu skemmtilegra að vinna með öðrum en einslega.

Röðun í hópa virtist oftast vera tilviljanakennd. Algengast var að nemendur veldu sig sjálf í hópa. Dæmi voru að vísu um að pá lentu sumir utangátta og kannski frekar einstaklingar sem samnemendur væntu ekki mikils af (Panitz, 1999; Slavin o.fl., 2003). Aðeins örfá dæmi voru um að kennari fæli einhverjum eða öllum í hópi ákveðin hlutverk við lausn viðfangsefnis eða mæltist til að hóparnir gerðu pað sjálfir. Markviss hópskipan og ákveðin hlutverk hvers og eins í hópi eru pættir sem lögð er áhersla á í samvinnunámi, ýmist undir leiðsögn kennara eða í höndum nemenda sjálfra. Fjöldi í hópi var yfirleitt tveir til fjórir nemendur, sem er í samræmi við pað sem fræðin segja um hæfilega hópstærð (Joyce o.fl., 2015). Degar reynt var að greina inntaksleg markmið viðfangsefna á breiðum grunni var svo að sjá að pau skiptust nokkuð jafnt milli pess að pekkingaröflun væri í brennidepli og að nemendahópar hefðu tækifæri til frumkvæðis eða sköpunar. En komið hefur fram að samvinnuverkefni veiti nemendum mun frekar tækifæri til frumkvæðis og sköpunar en einstaklingsverkefni (Gerður G. Óskarsdóttir, 2018), sem í sjálfu sér er rök fyrir áherslu á samvinnu.

Ekki verður auðveldlega metið á grunni vettvangslýsinganna hvort fram fór samvinnunám í takt við skilgreiningar fræðimanna (sbr. hér framar). Fáein dæmi voru um einstaka pætti samvinnunáms, til dæmis pegar ljóst var að kennari ætlaðist til sameiginlegrar lokaafurðar hópsins, raðaði í hópana með markvissum hætti eða útdeildi hlutverkum (sbr. Davidson og Major, 2014; Farmer, 2017; Ingvar Sigurgeirsson, 2013; Johnson og Johnson, 1999; Kagan og Kagan, 2009; Slavin, 2008). Dannig var að sjá að óformlegra skipulag, sem nefnt var hópvinna af ýmsu tagi, hefði vinninginn.

Hér er gengið út frá pví að hópstarf í námi eigi að sverja sig í ætt við lýðræði. Litið er svo á að bæði kennarastýrt samvinnunám og nemendastýrð óformlegri hópvinna geti verið lýðræðisleg. Megineinkenni á skipulagi lýðræðislegs samstarfs voru ekki áberandi í samvinnustundum sem fylgst var með eða bar á góma í nemendaviðtölunum (sjá umfjöllun í inngangi). Dau eru reyndar mörg pau sömu og eiga við um samvinnunám og margvíslega hópvinnu. Svo var ekki að sjá að viðtekið væri að nemendahópar settu sér starfsreglur eða semdu um verkaskiptingu sín á milli, ein og sér eða undir haldleiðslu kennara, enda kvörtuðu nemendur talsvert undan misjöfnu vinnuframlagi. Krafan um að hver og einn legði sitt af mörkum virtist pví ekki vera sterk í hugum allra. Út frá gögnunum var ekki unnt að meta hvernig leyst var úr ágreiningsefnum, tekið tillit til ólíkra sjónarmiða í hópunum eða ólíkum áherslum mætt. Dað er efni í aðra rannsókn.

\section{Viðhorf nemenda byggð á reynslu}

Svarið við priðju rannsóknarspurningunni um viðhorf nemenda til samvinnu er í stuttu máli sagt að pau hafi verið tvíbent. Ýmist sögðu viðmælendur samvinnu bestu leið til náms eða poldu hana alls ekki. Pegar nemendur forgangsröðuðu myndum af æskilegum námsaðstæðum höfðu aðrar aðstæður gjarnan forskot (Anna Kristín Sigurðardóttir og Sigrún Harpa Magnúsdóttir, 2018). Viðhorfin mótuðust trúlega af upplifun peirra af skipulagi samvinnuverkefna og pátttöku hvers og eins í peim. Nemendur lögðu meðal annars ríka áherslu á sjálfsákvörðun um niðurröðun í 
hópa. Pað getur bent til pess að vani hafi verið að nemendur fengju að ráða hópskipan, kynnu pví vel og vildu pví hafa pað pannig. Af vettvangslýsingunum mátti einnig ráđa að langalgengast væri að nemendur röðuðu sér sjálf í hópa, í einstaka tilvikum með aðkomu kennara. Viðmælendur voru pó meðvituð um að pað gæti leitt til pess að einhver yrði útundan. Jafnframt virtist liggja pungt á sumum að misvægi í vinnuframlagi væri oft mikið í samvinnuverkefnum, bæði í vilja til verka og getu, auk pess sem kvartað var undan spjalli utan efnis. Detta dregur athyglina að skipulagi samvinnunnar. Ef til vill benda hugleiðingar nemenda til pess að kennarar undirbúi ekki samvinnuverkefni nægjanlega eða ræði ekki við nemendur um undirbúning peirra sjálfra. Átt er við pað að vekja athygli á kostum pess að vinna með ólíkum einstaklingum, setja sér vinnureglur eða skilgreina verkaskiptingu í samvinnunni, frekar en skipta með sér verkum og vinna síðan einslega. Minna má á kennarann sem beindi pví til priggja manna hópa að skipta með sér að vera hvetjari, tímavörður og talsmaður. Pessi atriði skipta máli, hvort sem um er að ræða skipulagt samvinnunám, að hluta til stýrt af kennara, eđa hópvinnu par sem nemendur sjálfir eru meira við stjórnvölinn (Davidson og Major, 2014; Kagan og Kagan, 2009; Laal og Laal, 2012).

Djálfun í samvinnu krefst pess að allar hliðar hennar séu uppi á borðinu og ræddar, par með talinn tilgangurinn, skipulagið og framlag hvers og eins, jafnt sem mikilvægi tillitssemi og viðbrögð við ólíkum sjónarmiðum eða ágreiningsefnum. Pá má ætla að í henni felist nám í lýðræði sem liður í námi til lýðræðis. Dessir pættir virtust ekki vera nemendum ofarlega í huga pegar rætt var um samvinnu í námi. Dað getur bent til pess að viðmælendur hafi ekki vanist slíkri umræðu.

\section{Lokaord}

Draga má prjár ályktanir af pessari rannsókn: Í fyrsta lagi virðist vera gjá milli opinberrar fjölpjóðlegrar og innlendrar stefnumörkunar um lýðræðislegt samstarf og pess sem fram fer í skólastofum framhaldsskólanna. Hún gæti stafað af pví að ekki liggi fyrir pekking á viðkomandi stefnumörkun 1 skólunum, menn hafi ekki áhuga á að fylgja henni eða stuðning skorti. Detta leiðir hugann meðal annars að „eignarhaldi“ á námskránni. Í öðru lagi má velta fyrir sér skýrleika aðalnámskrár, til dæmis í skilgreiningu á „lýðræðislegu samstarfi“" (Mennta- og menningarmálaráđuneyti, 2011c), sem vekur upp spurningu um tengsl útgefenda aðalnámskrár og peirra sem starfa í skólunum. Loks er hér ef til vill aðeins að verki tregða til breytinga (sbr. Jón Torfa Jónasson, 2016).

Rannsókn sem beindist enn frekar að samvinnu nemenda og lýðræðislegri hlið hennar væri verðugt viðfangsefni. Pá væri áhugavert að skoða framkvæmdina nánar, jafnt hlut nemenda sem kennara. Áhugavert væri einnig að varpa ljósi á viðhorf kennara til gildis, skipulags og framkvæmdar lýðræðislegs samstarfs nemenda.

Рað er von höfundar að niðurstöðurnar leiði til pess að samvinna nemenda í einstökum skólum verði tekin til ítarlegrar endurskoðunar með hliðsjón af fjölpjóðlegri og innlendri stefnumörkun um pjálfun í lýðræðislegu samstarfi og fyrirliggjandi stuðningsefni (Keating, 2009; Gollob o.fl., 2008). Par undir fellur umfang samstarfs og skipulag. Í endurmati á kennsluháttum er páttur stjórnenda jafnt sem kennara mikilvægur (Guðrún Ragnarsdóttir, 2018). Slík endurskoðun getur verið pýðingarmikill liður í að próa lýðræðishugsun meðal ungs fólks (Sigrún Aðalbjarnardóttir, 2015). En ekki síður mætti pannig hlúa að og styrkja lýðræðið á viðsjárverðum tímum sem nú má sjá í próun stjórnmála, stöðu loftlagsmála og umfangi auðhringavalds og hryðjuverkaógnar (sbr. Humes, 2017; Tam, 2018). Áréttað skal að grundvallarpættir lýðræðis verða ekki lærðir nema með pjálfun í samskiptum og samvinnu við aðra (Slavin o.fl., 2003; Wolfgang Edelstein, 2010).

\section{Aftanmálsgrein}

[1] Megingagnasöfnun í rannsókninni Starfshættir í framhaldsskólum fór fram á tímabilinu október 2013 til nóvember 2014 í níu framhaldsskólum, auk pess sem rannsóknartækin voru 
forprófuð í tíunda skólanum. Gögnin eru vettvangslýsingar á 130 kennslustundum, yfir 60 afrituð viðtöl við nemendur (hópviðtöl), kennara og stjórnendur, ljósmyndir úr kennslustofum, kennsluáætlanir og önnur skrifleg gögn. Fimmtán manna hópur fræðafólks við Menntavísindaog Félagsvísindasvið Háskóla Íslands tók pátt í gagnasöfnuninni. Rannsóknin naut styrkja úr Rannsóknarsjóði Háskóla Íslands á árunum 2013-2015 og frá Norræna öndvegissetrinu Justice Through Education in the Nordic Countries, styrktu af NordForsk, 2013-2018. Úrvinnsla gagna fyrir pessa grein var styrkt af Hagpenki, félagi höfunda fræðirita og kennslugagna. Við pökkum sérstaklega framhaldsskólunum sem veittu aðgang að starfinu í rannsóknarskyni.

\section{Upper secondary student collaboration: A link to learning for democracy}

In international discourse from the turn of this century, special attention has been drawn to democracy in education, following policy initiatives from the European Council (2010) and the European Commission (2017) on democratic schooling and citizenship education. Student collaboration in various forms, which is the focus of this paper, is a key concept in definitions of democratic teaching approaches, as a means of learning "in democracy" and "for democracy". These influences can be traced in Icelandic curriculum guides from 2011, where democracy and human rights are listed as one of the six fundamental pillars of education at preschool, primary and secondary levels. This emphasis on democratic student collaboration is, indeed, not a new phenomenon. It can be traced to Dewey (1916) or even further back. In the literature, a distinction has been made between cooperation and collaboration: On the one hand, formal cooperation, often referred to as thorough planning by the teacher where group goals and individual accountability are highlighted; on the other hand, more informal collaboration, rather used as an umbrella phrase for various forms of students working together. The terms collaboration, coworking and group work are used alternately, and on an equal basis, in this paper. On this foundation, it was presumed interesting to investigate student group work in Icelandic schools. Thus, the aim of this paper is to shed light on the scope and organization of upper secondary students' collaboration in the classroom, as well as their attitudes towards working together.

This study is part of a larger research project: Teaching and Learning in Icelandic Upper Secondary Schools (students aged 16 to 19), aimed at obtaining a holistic view of the Icelandic upper secondary school (see Gerdur G. Oskarsdottir et al., 2018). The data were collected by 15 researchers in nine upper secondary schools around the country, selected as a stratified sample from a total of 31. Firstly, this study was based on classroom observations in 130 academic and vocational lessons of varied length, a total of 167 hours; and secondly, on interviews with 17 student focus groups, including 56 volunteers, 18 years or older. Data were analyzed in the light of international policy making on democratic collaborative endeavour.

The results revealed some kinds of collaboration between two or more students in $36 \%$ of the lessons observed (47 of 130). The proportion of time for collaboration (the number of minutes counted) was $17 \%$ of the total time observed (28 hours of 167). However, there was a difference among individual schools and school subjects. In one of the schools, $34 \%$ of the total observed lessons was devoted to some kind of collaboration, but only $3 \%$ in another school. Within seven categories of subjects, group work was most often detected in the mother tongue and foreign languages, or in over half of the lessons observed in these subjects. No difference was revealed between beginning and further courses in this respect. The number of students in classes or arrangement of furniture in classrooms seemed not to have been an issue. 
Students' attitudes towards coworking were both positive and negative in individual focus groups, and therefore their opinions could hardly be linked to individual schools. Three main concerns were expressed by the students: the arrangement of students into groups, complaining that the teachers "almost always" decided the members of each group, too large groups resulting in free riders or freeloaders, and small talk.

Three categories of organization of student collaboration in the classrooms were analyzed: a) collaboration or formal cooperation organized by the teacher, followed by students working together on solving an assignment, divided into a few groups ( $59 \%$ of lessons provided for some kinds of group work); b) collaboration prescribed by the teacher, but students in individual groups almost immediately distributed the work among themselves and then worked on it individually (26\%); c) optional group work; that is, the teacher said they could work together if they so preferred (15\%). Further investigation revealed the average size of groups as three to four students. Usually the students chose the group to join and decided the processing of the work. Thus, it was rare that the teachers arranged students into groups or decided the role of individual members of groups, these being characteristic features of formal cooperation. Free riders seemed to be a problem which was seldom addressed. Accordingly, it can be concluded that students' collaboration was not thoroughly organized, and many students' negative attitudes towards working together could be based on that experience. Finally, it is emphasized that fundamental components of democratic collaboration can only be learned through practice.

Key words: collaboration, cooperation, group work, democratic teaching approaches, upper secondary school.

\section{Um höfundinn}

Gerður G. Óskarsdóttir (gerdurgo@simnet.is) lauk doktorsprófi í menntunarfræði frá Kaliforníuháskóla í Berkeley 1994, meistaraprófi í námsráđgjöf frá Bostonháskóla 1981, BA-prófi frá Háskóla Íslands 1969 og kennaraprófi frá Kennaraskóla Íslands 1964. Gerður hefur starfað sem kennari og stjórnandi á grunn-, framhalds- og háskólastigi, ráðunautur menntamálaráðherra og yfirmaður leik- og grunnskóla Reykjavíkurborgar. Rannsóknir hennar hafa einkum snúist um brotthvarf, tengsl menntunar og starfs, náms- og starfsráðgjöf, kennsluhætti og skil skólastiga.

\section{About the author}

Gerður G. Óskarsdóttir (gerdurgo@simnet.is) completed a PhD in educational administration from the University of California at Berkeley in 1994, a MEd in school counseling from Boston University in 1981, a BA from the University of Iceland 1969, and diplomas leading to teaching certificates in 1971 and 1964. Gerður has served as teacher and administrator at primary, secondary and university levels and has been a consultant to the minister of education and superintendent of schools in the Reykjavik district. Her research has focused on drop outs, school-to-work relations, school counseling, teaching and learning, and educational transitions.

\section{Heimildir}

Anna Kristín Sigurðardóttir og Sigrún Harpa Magnúsdóttir. (2018). Nemendamiðað námsumhverfi: Hugmyndir framhaldsskólanemenda um kjöraðstæður til náms. Netla - veftímarit um uppeldi og menntun. Sérrit 2018 - Framhaldsskólinn íbrennidepli. Sótt af http://netla.hi.is/serrit/2018/framhaldskolinn_brennidepli/02.pdf

Arató, F. (2015). How does co-operative learning contribute to the prevention of discrimination and violence in schools? Í P. Mompoint-Gaillard og I. Lázár (ritstjórar), Developing competences for democracy. 60 activities to learn and assess transversal attitudes, skills and knowledge (TASKs). Pestalozzi Series 4 (bls. 22-31). Strasbourg: Evrópuráðið. 
Barnasáttmáli Sameinuðu pjóðanna. (1989). Sótt af http://www.barnasattmali.is/barnasattmalinn/barnasattmalinnheildartexti.html

Bruffee, K. A. (1995). Sharing our toys: Cooperative learning versus collaborative learning. Change, 27(1), 12-18.

Carlgren, I., Klette, K., Mýrdal, S., Schnack, K. og Simola, H. (2006). Changes in Nordic teaching practices: From individualised teaching to the teaching of individuals. Scandinavian Journal of Educational Research, 50(3), 301-326.

Clark, J., Laing, K., Tiplady, L. og Woolner, P. (2013). Diamond ranking activity. Making connections: Theory and practice of using visual methods to aid participation in research. Newcastle: Research Centre for Learning and Teaching, Newcastle University.

Davidson, N. og Major, C. H. (2014). Boundary crossings: Cooperative learning, collaborative learning, and problem-based learning. Journal on Excellence in College Teaching, 25(3 og 4), 7-55.

Dewey, J. (1966). Democracy and education. An introduction to the philosophy of education. New York: The Free Press (frumútgáfa 1916).

Dewey,J. (2000). Reynsla og menntun (Gunnar Ragnarsson pýddi). Reykjavík: Rannsóknarstofnun Kennaraháskóla Íslands (frumútgáfa 1938).

Dewey, J. (2010). Pörfin fyrir heimspeki menntunar (Gunnar Ragnarsson pýddi). Í Jóhanna Einarsdóttir og Ólafur Páll Jónsson (ritstjórar), John Dewey í hugsun og verki. Menntun, reynsla og lýdraði (bls. 197-206). Reykjavík: RannUng, Heimspekistofnun Háskóla Íslands og Háskólaútgáfan. (frumútgáfa 1934).

Elsa Eiríksdóttir, Guðrún Ragnarsdóttir og Jón Torfi Jónasson. (2018). Dversagnir og kerfisvillur? Kortlagning á ólíkri stöðu bóknáms- og starfsnámsbrauta á framhaldsskólastigi. Netla - veftímarit um uppeldi og menntun. Sérrit $2018-$ Framhaldsskólinn í brennidepli. Sótt af http://netla.hi.is/serrit/2018/framhaldskolinn_brennidepli/07.pdf

European Commission/EACEA/Eurydice. (2017). Citizenship education at school in Europe - 2017. Eurydice Report. Luxembourg: Publications Office of the European Union.

Evrópuráðið. (2010). Sáttmáli Evrópuráđsins um lýðreeðis- og mannréttindamenntun (íslensk pýðing). Reykjavík: Evrópuráđið og Mennta- og menningarmálaráðuneytið.

Farmer, L. M. (2017). Kagan cooperative learning structures and the effects on student achievement and engagement. Science and Mathematics Education Commons. Orange City, IA: Northwestern College.

Gerður G. Óskarsdóttir. (2012). Skil skólastiga. Frá leikskóla til grunnskóla og grunnskóla til framhaldsskóla. Reykjavík: Háskólaútgáfan og Skóla- og frístundasvið Reykjavíkurborgar.

Gerður G. Óskarsdóttir. (2018). Frumkvæði nemenda: Innlit í kennslustundir níu framhaldsskóla. Netla - veftímarit um uppeldi og menntun. Sérrit 2018 - Framhaldsskólinn i brennidepli. Sótt af http://netla.hi.is/serrit/2018/framhaldskolinn_brennidepli/06.pdf

Gerður G. Óskarsdóttir og rannsóknarhópur um starfshætti í framhaldsskólum. (2018). Starfshættir í framhaldsskólum: Aðdragandi og framkvæmd rannsóknar 2012-2018. Netla - veftímarit um uppeldi og menntun. Sérrit 2018 - Framhaldsskólinn í brennidepli. Sótt af http://netla.hi.is/serrit/2018/framhaldskolinn_brennidepli/01.pdf

Gollob, R., Huddleston, T., Krapf, P., Rowe, D. og Taelman,W. (2008). Lifað i lýdrceði. Kennsluáatlanir fyrir efri bekki grunnskóla um l'́drađislega borgaravitund og mannréttindi (Helga Jónsdóttir og Dórgunnur Skúladóttir býddu). Reykjavík: Menntaog menningarmálaráđuneytið, Námsgagnastofnun og Evrópuráðið.

Goodlad, J. I. (2004). A place called school. New York: McGrawHill.

Guðrún Ragnarsdóttir. (2018). School leaders' perceptions of contemporary change at the upper secondary school level in Iceland. Interaction of actors and social structures facilitating or constraining change (óútgefin doktorsritgerð). Háskóli Íslands, Reykjavík.

Hafdís Ingvarsdóttir (2004). ,... ef pað er eitthvað sem peim pykir áhugavert. “ Enskukennsla við upphaf 21. aldar. Í Úlfar Hauksson (ritstjóri), Rannsóknir i félagsvísindum V (bls. 471-481). Reykjavík: Háskólaútgáfan.

Hewitt, R. S. (2006). Democratic education: A Deweyan reminder. Education and Culture, 22(2), 43-60. Sótt af https:// docs.lib.purdue.edu/eandc/vol22/iss2/art6

Humes, W. (2017). Re-shaping the map of educational studies: Lessons from Dewey's ‘Democracy and education'. Education in the North, 24(1), 16-26.

Ingvar Sigurgeirsson. (2013). Litróf kennsluaðferðanna. Handbók fyrir kennara og kennaraefni. Reykjavík: Iðnú.

Ingvar Sigurgeirsson, Elsa Eiríksdóttir og Ingólfur Ásgeir Jóhannesson. (2018). Kennsluaðferðir í 130 kennslustundum í framhaldsskólum. Netla - veftímarit um uppeldi og menntun. Sérrit 2018 - Framhaldsskólinn í brennidepli. Sótt af http:// netla.hi.is/serrit/2018/framhaldskolinn_brennidepli/09.pdf

Johnson, D. W. og Johnson, R. T. (1991). Learning together and alone: Cooperative, competitive and individualistic learning (3. útgáfa). Boston: Allyn \& Bacon.

Johnson, D. W. og Johnson, R. T. (1999). Making cooperative learning work. Theory Into Practice, 38(2), 67-73.

Johnson, D. W., Johnson, R. T. og Smith, K. A. (1998). Cooperative learning returns to college: What evidence is there that it works? Change, 30(4), 26-35. 
Joyce, B. R., Weil, M. og Calhoun, E. (2015). Models of teaching (9. útgáfa). Boston: Pearson.

Jón Torfi Jónasson. (2016). Educational change inertia and potential futures. Why is it difficult to change the content of education? European Journal of Futures Research, 4(1), 1-14. doi:10.1007/s40309-016-0087-z

Kagan, S. og Kagan, M. (2009). Kagan cooperative learning. San Clemente, CA: Kagan Publishing.

Keating, S. (ritstjóri). (2009). Leiðir kennara til að efla menntun á sviði borgaravitundar og mannréttinda: rammadrög að haefnipróun (Helga Jónsdóttir og Pórgunnur Skúladóttir pýddu). Strasbourg: Evrópuráđið.

Laal, M. og Laal, M. (2012). Collaborative learning: What is it? Procedia - Social and Behavioral Sciences, 31, 491-495. doi. org/10.1016/j.sbspro.2011.12.092

Lög um framhaldsskóla nr. 92/2008.

Maitles, H. og Gilchrist, I. (2005). 'We're citizens now'!: The development of positive values through a democratic approach to learning. Journal of Critical Education Policy Studies, 3(1), 85-111.

Mennta- og menningarmálaráduneyti. (2011a). Ađalnámskrá leikskóla 2011. Reykjavík: Höfundur.

Mennta- og menningarmálaráduneyti. (2011b). Aðalnámskrá grunnskóla: Almennur hluti 2011. Reykjavík: Höfundur.

Mennta- og menningarmálaráđuneyti. (2011c). Aðalnámskrá framhaldsskóla: Almennur hluti 2011. Reykjavík: Höfundur.

Ólafur Páll Jónsson. (2010). Hugsun, reynsla og lýðræði. Í Jóhanna Einarsdóttir og Ólafur Páll Jónsson (ritstjórar), John Dewey í hugsun og verki. Menntun, reynsla og lýdraæzi (bls. 13-41). Reykjavík: RannUng, Heimspekistofnun Háskóla Íslands og Háskólaútgáfan.

Ólafur Páll Jónsson og Póra Björg Sigurðardóttir. (2012). Lýðreæði og mannréttindi - Grunnpáttur menntunar á öllum skólastigum. Ritröð um grunnpatti menntunar. Reykjavík: Mennta- og menningarmálaráðuneytið og Námsgagnastofnun.

Panitz, T. (1999). Collaborative versus cooperative learning: A comparison of the two concepts which will help us understand the underlying nature of interactive learning. Lanham, ML: ERIC.

Sigrún Aðalbjarnardóttir. (2015). Ákall og áskoranir:Vegsemd og virðing í skólastarfi. Netla - Veftímarit um uppeldi og menntun. Sótt af http://netla.hi.is/greinar/2015/alm/005.pdf

Slavin, R. E. (2008). Cooperative learning, success for all, and evidence-based reform in education. Éducation \& Didactique, 2(2), 149-157.

Slavin, R. E. (2014). Cooperative learning and academic achievement: Why does groupwork work? Anales de Psicología, 30, 785-791. doi:10.6018/analesps.30.3.201201

Slavin, R. E., Hurley, E.A. og Chamberlain,A. (2003). Cooperative learning and achievement:Theory and research. Í I. B. Weiner (ritstjóri), Handbook of psychology, Volume 7, Educational Psychology (bls. 177-198). Hoboken, NJ:Wiley \& Sons.

Svanhildur Kr. Sverrisdóttir. (2014). Ef að er gád: Afdrif aðalnámskrár í íslensku á unglingastigi grunnskóla og í framhaldsskóla (óútgefin doktorsritgerð). Háskóli Íslands, Reykjavík.

Tam, H. (2018). Time to save democracy: How to govern ourselves in the age of anti-politics. Bristol: Bristol University Press.

Tyack, D. og Cuban, L. (1995). Tinkering toward utopia: A century of public school reform. Cambridge, MA: Harvard University Press.

UNICEF á Íslandi. (2015). Fyrstu Réttindaskólar á Íslandi. Alpjóðlegt verkefni UNICEF. Sótt af https://unicef.is/fyrstu-réttindaskólar-á-1́slandi

Wolfgang Edelstein. (2008). Hvað geta skólar gert til að efla lýðræði? Hæfni og færni í draumalandi. Í Dóra S. Bjarnason, Guðmundur Hálfdanarson, Helgi Skúli Kjartansson, Jón Torfi Jónasson og Ólöf Garðarsdóttir (ritstjórar), Menntaspor. Rit til heiðurs Lofti Guttormssyni sjötugum 5. apríl 2008 (bls. 65-78). Reykjavík: Sögufélag.

Wolfgang Edelstein. (2010). Lýðræði verður að læra! Netla - Veftímarit um uppeldi og menntun. Sótt af http://netla.hi.is/ greinar/2010/005/index.htm

Gerður G. Óskarsdóttir. (2018)

Samvinna framhaldsskólanemenda. Liður ílærdómi til lýðræðis.

Netla - veftímarit um uppeldi og menntun. Sérrit 2018 - Framhaldsskólinn í brennidepli.

Menntavísindasvið Háskóla Íslands.

Sótt af http://netla.hi.is/serrit/2018/framhaldskolinn_brennidepli/10.pdf

DOI: https://doi.org/10.24270/serritnetla.2019.10 